(8) allyl bromide は塩化カルシウムで乾燥し, 蒸留して用いる。

（9）酢酸メチルはいっしょに加えておき，グリニーヤル試薬が生成すると同時に反応させる方が，簡便で，収率も よい。

（10） はじめに多く加えてはいけない。加えすぎると，しばらくして反応がはげしくなり，反応を静めるために冷却 しすぎると，つぎに反応しにくくなる。

\title{
III. 性 質
}

mp 108 109 ${ }^{\circ} \mathrm{C} ; \mathrm{IR}(\mathrm{KBr}): 3400,1710 \mathrm{~cm}^{-1} ; \mathrm{NMR}\left(\mathrm{D}_{2} \mathrm{O}\right): \delta 2.72 \mathrm{ppm}$ (singlet, $\left.4 \mathrm{H}, \mathrm{CH}_{2}\right) 。$

\section{IV. 本法の利点}

メチル化した後のエーテル溶液の濃縮の過程とグリニャール反応の容器および溶媒の乾燥に留意すれば，再現性のあ る結果が得られる。出発物質として，入手しやすい 4 重水素酢酸を使用できることが本法の利点である。ここで得られ，

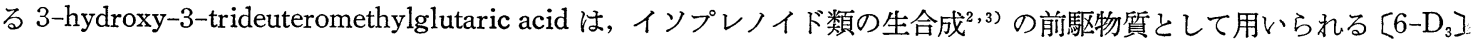
メバロン酸の合成中間体である。メバロン酸への合成については別項に述べる。

\section{引用文献}

1) T.H.J. Deboer, H.J. Backer, Rec. Trav. Chim. 73229 (1954)

2) T. Suga, T. Shishibori, S. Kimoto, Chem. Lett. 1972129

3) T. Suga, T. Shishibori, S. Kimoto, Chem. Lett. 1972313

\section{3-Iododenzanthrone}

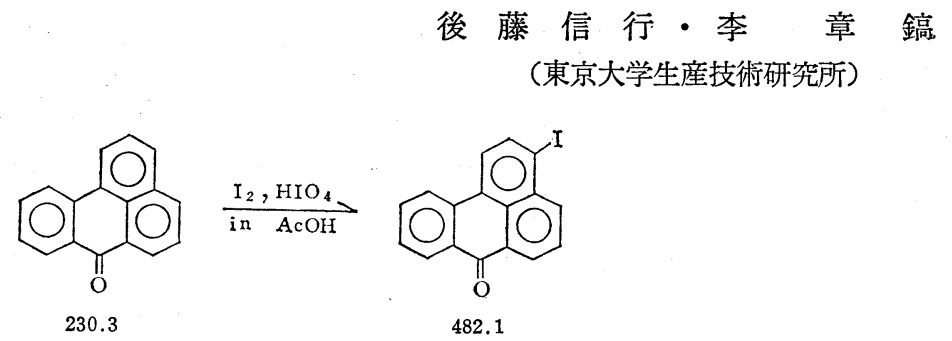

I. 製 法

温度計, 冷却管, 滴下漏斗およびかきまぜ機を付けた $1 l$ の四つロフラスコに酢酸 $500 \mathrm{~m} l$, 濃硫酸 $25 \mathrm{~m} l$ をれ, かきまぜながら $45^{\circ} \mathrm{C}$ で benzanthrone $4.60 \mathrm{~g}(0.02 \mathrm{~mol})$ を加え溶解する。つぎに過ヨウ素酸 $\left(\mathrm{HIO}_{4} \cdot 2 \mathrm{H}_{2} \mathrm{O}\right) 4.0 \mathrm{~g}$ : $(0.018 \mathrm{~mol})$ とヨウ素 $4.0 \mathrm{~g}(0.031 \mathrm{~mol})$ のエタノール $50 \mathrm{ml}$ 溶液を 5 分間で加え, $45 \sim 50^{\circ} \mathrm{C}$ (注意 1 ) で 6 時間か きまぜる。反応混合物を $2 \%$ 亜硫酸ナトリウム水溶液 $1.5 l$ にかきまぜながら注入し，沈殿物を口別，水洗し $100^{\circ} \mathrm{C}$ で乾燥して粗生成物 $6.70 \mathrm{~g}$ を得た。

つぎに粗生成物をベンゼン $1 l$ と少量の活性炭を加え煮沸した後, 熱口過しさらに溶媒を完全に留去した後, ベンゼ ンージクロロエタンの等量混合物 $115 \mathrm{ml}$ から再結晶し，3-iodobenzanthrone $3.410 \mathrm{~g}$ を得る (収率 48～55\%)。

\section{II. 注 意 事 項}

(1) 温度が $50^{\circ} \mathrm{C}$ 以上になるとジョード化されやすくなるので $50^{\circ} \mathrm{C}$ 以上にならぬようにする。

\section{III. 性質}

黄色結晶, $\mathrm{mp} 178 \sim 179^{\circ} \mathrm{C}$, o-ジクロロベンゼン, クロロベンに易溶, ベンゼンには比較的よく溶けるがエーテル, アセトン, メタノールに難溶, 硫酸呈色は赤色。 


\section{IV. 本法の利点}

従来 benzanthrone のヨード誘導体 ${ }^{12}$ は相当するアミノ化合物の Griess 反応により得ている。 また著者らは先に benzanthrone の直接ヨード化生成物よりカラムクロマトグラフィーを用いて 3-iodobenzanthrone ${ }^{2)}$ を分離したが，本法では再結晶法を用い容易に目的物を得ることができる。

\section{引用文献}

1) 後藤信行, 永井芳男ら，有合化 27775 (1969)

2) 後藤信行, 李章鎬, 有合化 30386 (1972)

\section{3,9-Diiodobenzanthrone}

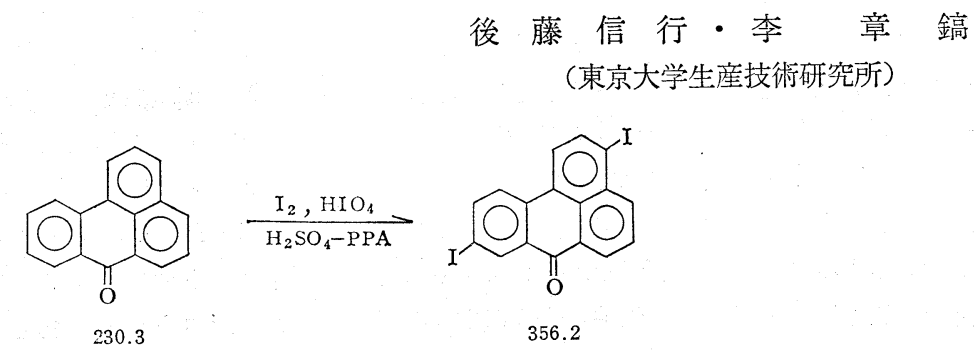

\section{I. 製 法}

温度計, 滴下漏斗, 塩化カルシウム管抢よびかきまぜ機をつけた $1 l$ の四つロフラスコに濃硫酸 $700 \mathrm{~g}$, ポリリン酸 $300 \mathrm{~g}$ (注意 1 ) を入れ，かきまぜながら $40 \sim 50^{\circ} \mathrm{C}$ で benzanthrone $23 \mathrm{~g}(0.1 \mathrm{~mol})$ を加え溶解する。つぎにエタノ ール $300 \mathrm{ml}$ にヨウ素 $30 \mathrm{~g}(0.12 \mathrm{~mol})$ ，過ヨウ素酸（注意 2$) 10 \mathrm{~g}(0.04 \mathrm{~mol})$ を溶かした溶液を水浴で $25 \sim 30^{\circ} \mathrm{C}$ に 保ち，はげしくかきまぜながら約 1.5 時間かけて滴下する（注意 3 )。反応混合物をさらにその温度で 10 時間かきま ぜ，1夜放置すると赤色よりじょじょに茶色味を帯びたゼり一状になる。これを $2 l$ の水中にかきまぜながら注入し， 熱の発生と共に生じる黄色の沈殿物を口別，水洗し，さらに $5 \%$ 亜硫酸ナトリウム水溶液で洗い（注意4）ヨウ素を 完全に遊離した後ふたたび氷洗し, $100^{\circ} \mathrm{C}$ で乾燥すると粗生成物 $44 \mathrm{~g}$ を得る。このものを少量の活性炭と共にモクク ロロベンゼン $2 l$ から再結晶すると $\mathrm{mp} 287 \sim 288^{\circ} \mathrm{C}$ の純品 $30.8 \mathrm{~g}(64 \%)$ が得られる。

\section{II. 注 意 事 項}

（1）五酸化リン $300 \mathrm{~g}$, 水 $40 \mathrm{ml}$, リン酸 $360 \mathrm{~m} l$ を加熱溶解してつくる。

(2) 和光特級 $\mathrm{HIO}_{4} \cdot 2 \mathrm{H}_{2} \mathrm{O}$ を使用したが一級でもさしつかえない。

（3） 反応温度が高くなるとヨウ素が昇華するので $30^{\circ} \mathrm{C}$ 以上にならないように注意する。

(4) 遊離ヨウ素を十分に除去しないと再結晶の際ヨウ素を含む赤味を帯びた結晶になることがある。

\section{III. 性 質}

$\mathrm{mp} 287 \sim 288^{\circ} \mathrm{C}$ の黄色針状結晶。エーテル，アセトン，テトラヒドロフラン，メタノール，エタノール等の有機溶 剤に難溶, クロロベンゼン，o-ジクロロベンゼンには比較的よく溶ける。

\section{IV. 本法の利点}

従来 benzanthrone の直接八ロゲン化による 3,9-ジハロゲン誘導体の合成はクロル化とブロム化に限られていた。 本法を用いると簡単でしかも収率も比較的良好にヨウ素誘導体 ${ }^{1}$ を得ることができる。

\section{引用文献}

1）後藤信行・李章鎬，有合化 $\mathbf{3 0} 386$ (1972) 